\title{
Morphological and Biochemical Changes in Vigna radiata and Spinacia oleracea Induced by Fluoride Contamination in Soils
}

\author{
Rakhi Tyagi ${ }^{1}$, Jyoti Luhach ${ }^{2}$, A.K. Mishra ${ }^{3}$ and Smita Chaudhry ${ }^{2} *$ \\ ${ }^{1}$ ICAR- National Bureau of Plant Genetic Resources, New Delhi, India \\ ${ }^{2}$ Institute of Environmental Studies, Kurukshetra University, Kurukshetra, Haryana, India \\ ${ }^{3}$ Graduate School of Global Environmental Studies, Kyoto University, Kyoto, Japan \\ *Corresponding author
}

\section{A B S T R A C T}

More than sixty million Indians reside in endemic areas of fluorosis and are at risk of developing fluorosis in 200 districts from 20 states of India. Keeping in mind the severity of fluoride $(F)$ problems, this study is an effort to investigate the effect of $F$ contaminated

\section{Keywords}

Sodium fluoride,

Spinach, Mung

bean, Chlorophyll,

Growth physiology.

Article Info

Accepted:

04 April 2017

Available Online:

10 May 2017 soils on germination, plant growth and physiology of important pulse, mung bean (Vigna radiata) and green leafy vegetable spinach (Spinacia oleracea). This study was carried out with completely randomized block design under controlled environmental conditions in green house. The results of this study showed that under high (Sodium fluoride) NaF conc. $(0.15 \mathrm{mg} / \mathrm{l})$, the percent germination was observed to be decreased by $20 \%$ in spinach compared to control. Similarly, the shoot length was found to be decreased more in spinach $(51 \%)$, than in mung bean. The root length was also observed to decrease by $64.3 \%$ and $59.6 \%$ in mung bean and spinach respectively as compared to control, indicating the differential sensitivity of these crops. The content of chlorophyll-a, chlorophyll-b and total chlorophyll of leaves in both the crops decreased monotonically as toxicity level of $F$ increased. Treatment with highest F concentration $(0.15 \mathrm{mg} / \mathrm{l})$, showed decreased vigour index in spinach. Shoot dry wt. was positively correlated $(\mathrm{p}<0.05)$ with root length, chl a, b and total chl., root dry wt. and root shoot ratio. However, shoot dry wt. was negatively correlated with shoot length, seed germination and vigour index. This study concludes that soil contaminated with $\mathrm{F}$ has negative efffects on the growth physiology and biochemical characteristics of mung bean and spinach.

\section{Introduction}

Globally $\mathrm{F}$ contamination is recognized as a serious threat to biotic component of the environment, affecting more than 266 million people (Amini et al., 2008). F is a strong electronegative element widespread in the environment, including soil, air, water and the vegetation (Jha et al., 2009). Mining and processing of phosphate rock and its use as agricultural fertilizer, as well as the manufacturing of aluminum, the combustion of coal and other manufacturing processes are major sources of $\mathrm{F}$ into the environment. Fertilization and irrigation with water having high concentration of $\mathrm{F}$ result in accumulation of $F$ gradually in the soil and finally restrain the germination and growth physiology of the crops. According to World Health Organization standards, the $\mathrm{F}$ in drinking water should be within the limit of $1 \mathrm{mg} / \mathrm{l}$. However, the Ministry of Health, Government 
of India, has prescribed 1.0 and $2.0 \mathrm{mg} / \mathrm{l}$ as permissive and excessive limits for $\mathrm{F}$, respectively in drinking water. Yu, (1996) reported marked decrease in root elongation of Vigna radiata.

F content of both leafy and root vegetables usually do not differ appreciably from those of cereals with an exception of spinach and onion, which showed enriched and accumulative capacity for F (Jha et al., 2009). Pant et al., (2008) studied the growth of shoot and root in many seedlings at $0.02 \mathrm{M} \mathrm{NaF}$ and noted that the length of shoots was reduced more even though the root length is also reduced except the root lengths in tomato seedlings. Sabal and Khan et al., (2006) studied the effect of sodium $F$ on seed germination and seedling growth in cluster bean (Cyamopsis tetragonoloba). We hypothesized that $\mathrm{F}$ concentration within standards would not have any adverse effect on crop germination and growth physiology of mung bean and spinach.

Keeping in mind the severity of $F$ problems in our country and the effectiveness of phytoremediation methods in removal of contaminants from soil, water and sediments, this study was designed to evaluate the effect of $\mathrm{F}$ on germination, morphological and biochemical changes in mung bean and spinach. Mung bean is a tropical crop grown in warm season; requires full sunlight or at least 8 to 10 hours of sunlight daily. On the other hand, spinach is best grown in moist, nitrogen rich soil and has deep taproot system. In India, both the crops are of utmost importance as major pulse and vegetable, respectively.

\section{Materials and Methods}

During spring season of 2015, a pot experiment for evaluation of growth performance of Vigna radiata (Muskan-851) and Spinacia oleracea (HB-24) under different concentrations of $\mathrm{F}$ (control, 0.01, $0.05,0.10$ and $0.15 \mathrm{mg} / \mathrm{l}$ ) was carried out in green house of the Institute of Environmental Studies, Kurukshetra University, Kurukshetra, Haryana, India. Before pot experiment, the seeds were sterilized under laboratory conditions.

\section{Field testing of $\mathbf{F}$ toxicity}

A pot experiment was carried out with completely randomized block design in the green house. In total, 30 pots ( 5 treatments $\times$ 2 crops $\times 3$ replications) filled with $5 \mathrm{~kg}$ homogeneous soils having sandy: loam $(1: 2)$ texture and $\mathrm{pH}$ (7.65). Soil medium was moderate with organic carbon $(0.45 \%)$, available nitrogen (181.8 $\mathrm{kg} \quad \mathrm{N} / \mathrm{ha})$, phosphorus $\left(15.6 \mathrm{~kg} \mathrm{P}_{2} \mathrm{O}_{5} / \mathrm{ha}\right)$ and potassium (220.0 kg K $2 \mathrm{O} / \mathrm{ha})$. Out of 30 pots, 6 were taken as control with no $\mathrm{F}$ and 24 for different concentrations of F. Before sowing, healthy seeds from both the crops were soaked in distilled water overnight and then 10 seeds were sown in each pot in a circular fashion with equal distance. Initially pots were irrigated with distilled water until germination and then different concentration of $\mathrm{NaF}$ were applied on 7, 14, 21 and 28 day from the date of sowing. Finally, after 40 days of sowing, both the crops were harvested for morphological (seed germination, shoot length, root length, shoot biomass, root biomass, root: shoot ratio and vigor index and biochemical analysis (chl a, chl b and total chl.).

\section{Growth parameters}

Seed germination was observed as the number of seed germinated compared with total seed sown. Shoot length was taken by scale from base to top leaf and root length was taken after harvesting. Shoot biomass and root biomass were determined by putting samples in hot air oven at $100^{\circ} \mathrm{C}$ temperature. 


\section{Vigor index}

It was calculated as per the equation given by Anderson et al., (1973).

Vigor Index $=($ Root length + Shoot length $) \mathrm{x}$ Germination percentage

Estimation of chlorophyll a, b and total chlorophyll

To estimate chlorophyll, $100 \mathrm{mg}$ plant material (leaves) was crushed in $10 \mathrm{ml}$ of chilled acetone $80 \% \quad(\mathrm{v} / \mathrm{v})$ and was centrifuged at $10,000 \mathrm{rpm}$ for $15 \mathrm{~min}$. The residue was re-extracted with $5 \mathrm{ml}$ of $80 \%$ acetone. Both the supernatant were pooled and volume was made to $15 \mathrm{ml}$ with $80 \%$ acetone and optical density was measured at wavelength 663 and $645 \mathrm{~nm}$ for chlorophyll by using UV-Vis spectrophotometer.

Arnon's (1949) equations are as follows:

Chla $\left(\mathrm{mg} \quad \mathrm{g}^{-1}\right)=(0.0127) \times(\mathrm{A} 663)-$ $(0.00269) \times($ A645)

Chlb $\left(\mathrm{mg} \quad \mathrm{g}^{-1}\right)=(0.0029) \times(\mathrm{A} 663)-$ $(0.00468) \times(\mathrm{A} 645)$

Total Chl $\left(\mathrm{mg} \mathrm{g}^{-1}\right)=(0.0202) \times(\mathrm{A} 663)+$ $(0.00802) \times(\mathrm{A} 645)$

Where, $\mathrm{A}=\mathrm{Absorbance}$ at suffixed wavelength.

\section{Results and Discussion}

Contaminants such as $\mathrm{F}$ in soil-water system tend to accumulate in different parts of the plant and negatively influence the plant physiological and growth.

Present study was an attempt to evaluate the effect of $\mathrm{F}$ concentration on mung bean and spinach.

\section{Seed germination}

Seed germination in mung bean was least affected even with the highest dose $(0.15$ $\mathrm{mg} / \mathrm{l})$ considered in this study. However, with the same dose of F, 20\% reduction in seed germination was recorded in spinach (Table $1)$.

Failure in seed germination at high concentrations may be due to retardation in water uptake, cell divisions inhibition and embryo enlargement. The blockage of pathway for solute movement may lead to no or poor germination. Similar results were also demonstrated by Gadi et al., (2012) for mung bean and Zhang et al., (2014) for spinach.

\section{Shoot and root length}

Shoot and root length was observed to be decreased with increased concentration of $F$ in both the crops. With highest $\mathrm{NaF}(0.15$ $\mathrm{mg} / \mathrm{l}$ ), shoot length decreased by $51.0 \%$ in spinach, followed by $41.0 \%$ in mung bean as compared to control, respectively (Table 1). But, the effect of toxicity on root length was more in mung bean as compared to spinach (root length decreased by 64.3 and $59.6 \%$ in mung bean and spinach respectively) as compared to control, indicating the differential sensitivity of these crops (Table 1).

Root and shoot length reduction by $\mathrm{F}$ stress was due to unbalanced nutrient uptake by seedlings (Pant et al., 2008). Chakrabarti and Patra (2013) corroborated the negative effects of different doses of $\mathrm{F}$ on seed germination, shoot length, root length and vigour index on two varieties of paddy. $F$ prevented the dephosphorylation of phylin compound in the plant tissue and retarded the rate of seedling root growth during germination (Chang, 1966). 
Table.1 Growth physiological attributes of mung bean and spinach

\begin{tabular}{|c|c|c|c|c|c|c|c|c|}
\hline \multirow{2}{*}{$\begin{array}{l}\text { Treatment } \\
(\mathrm{mg} / \mathrm{l})\end{array}$} & \multicolumn{4}{|l|}{ Mung bean } & \multicolumn{4}{|l|}{ Spinach } \\
\hline & $\begin{array}{l}\text { Shoot } \\
\text { length }(\mathrm{cm})\end{array}$ & $\begin{array}{l}\text { Root length } \\
(\mathrm{cm})\end{array}$ & $\begin{array}{l}\text { Germinatio } \\
\mathrm{n}(\%)\end{array}$ & Vigour Index & $\begin{array}{l}\text { Shoot length } \\
(\mathrm{cm})\end{array}$ & $\begin{array}{l}\text { Root length } \\
(\mathrm{cm})\end{array}$ & $\begin{array}{l}\text { Germinatio } \\
\mathrm{n}(\%)\end{array}$ & Vigour Index \\
\hline $\begin{array}{c}\text { Control } \\
(0.00)\end{array}$ & $15.6 \pm 0.56^{\mathrm{a}}$ & $6.33 \pm 0.81^{\mathrm{a}}$ & 100.0 & $2196.6 \pm 135.7^{\mathrm{a}}$ & $7.30 \pm 0.81^{\mathrm{a}}$ & $6.76 \pm 0.25^{\mathrm{a}}$ & 80.0 & $1128.3 \pm 176.6^{\mathrm{a}}$ \\
\hline $\mathrm{T} 1(0.01)$ & $11.8 \pm 1.21^{b}$ & $3.76 \pm 0.90^{b}$ & 100.0 & $1556.6 \pm 196.5^{b}$ & $5.90 \pm 0.20^{b}$ & $5.03 \pm 0.61^{b}$ & 60.0 & $658.6 \pm 133.9^{b}$ \\
\hline $\mathrm{T} 2(0.05)$ & $10.8 \pm 1.75^{b c}$ & $2.73 \pm 1.36^{\mathrm{b}}$ & 100.0 & $1356.6 \pm 130.5^{\mathrm{bc}}$ & $4.80 \pm 0.26^{\mathrm{c}}$ & $3.53 \pm 1.05^{\mathrm{c}}$ & 50.0 & $410.6 \pm 168.3^{b c}$ \\
\hline T3(1.00) & $11.1 \pm 1.00^{\mathrm{bc}}$ & $2.43 \pm 0.51^{\mathrm{b}}$ & 100.0 & $1356.6 \pm 130.1^{\mathrm{bc}}$ & $5.60 \pm 0.60^{\mathrm{bc}}$ & $4.13 \pm 1.00^{\mathrm{bc}}$ & 30.0 & $300.3 \pm 187.7^{\mathrm{c}}$ \\
\hline $\mathrm{T} 4(1.15)$ & $9.20 \pm .624^{\mathrm{c}}$ & $2.26 \pm 0.32^{\mathrm{b}}$ & 100.0 & $1146.6 \pm 85.0^{\mathrm{c}}$ & $3.56 \pm 0.51^{\mathrm{d}}$ & $2.73 \pm 0.61^{\mathrm{c}}$ & 20.0 & $127.6 \pm 76.3^{c}$ \\
\hline
\end{tabular}

Values with the same lower case letters in a column denote no significant difference at $\mathrm{P}<0.05 ; \pm$ Standard Deviation

Table.2 Biomass in Mung bean and Spinach under different concentrations of $\mathrm{F}$

\begin{tabular}{|l|c|c|c|c|c|c|}
\hline \multirow{2}{*}{$\begin{array}{l}\text { Treatment } \\
(\mathrm{mg} / \mathrm{l})\end{array}$} & \multicolumn{3}{|c|}{ Mung bean } & & \multicolumn{3}{c|}{ Spinach } \\
\cline { 2 - 7 } & $\begin{array}{c}\text { Dry shoot wt. } \\
(\mathrm{g})\end{array}$ & $\begin{array}{c}\text { Dry root wt. } \\
(\mathrm{g})\end{array}$ & R:S ratio & Dry shoot wt. $(\mathrm{g})$ & Dry root wt. $(\mathrm{g})$ & R:S ratio \\
\hline Control $(0.00)$ & $1.43 \pm 0.04^{\mathrm{a}}$ & $0.36 \pm 0.25^{\mathrm{a}}$ & $0.25 \pm 0.16^{\mathrm{a}}$ & $2.03 \pm 0.02^{\mathrm{a}}$ & $0.90 \pm 0.01^{\mathrm{a}}$ & $0.44 \pm 0.00^{\mathrm{a}}$ \\
\hline T1(0.01) & $1.42 \pm 0.02^{\mathrm{a}}$ & $0.41 \pm 0.02^{\mathrm{a}}$ & $0.29 \pm 0.01^{\mathrm{a}}$ & $1.90 \pm 0.01^{\mathrm{b}}$ & $0.72 \pm 0.01^{\mathrm{b}}$ & $0.38 \pm 0.00^{\mathrm{b}}$ \\
\hline T2(0.05) & $1.35 \pm 0.03^{\mathrm{a}}$ & $0.36 \pm 0.02^{\mathrm{a}}$ & $0.26 \pm 0.00^{\mathrm{a}}$ & $1.64 \pm 0.02^{\mathrm{c}}$ & $0.52 \pm 0.00^{\mathrm{c}}$ & $0.31 \pm 0.00^{\mathrm{c}}$ \\
\hline T3(1.00) & $1.10 \pm 0.10^{\mathrm{b}}$ & $0.24 \pm 0.04^{\mathrm{a}}$ & $0.21 \pm 0.02^{\mathrm{a}}$ & $1.52 \pm 0.02^{\mathrm{d}}$ & $0.49 \pm 0.01^{\mathrm{d}}$ & $0.32 \pm 0.001^{\mathrm{d}}$ \\
\hline T4(1.15) & $1.05 \pm 0.04^{\mathrm{b}}$ & $0.20 \pm 0.10^{\mathrm{a}}$ & $0.19 \pm 0.10^{\mathrm{a}}$ & $1.36 \pm 0.02^{\mathrm{e}}$ & $0.47 \pm 0.01^{\mathrm{d}}$ & $0.34 \pm 0.01^{\mathrm{d}}$ \\
\hline
\end{tabular}

R:S-root: shoot ratio; Values with the same lower case letters in a column denote no significant difference at $\mathrm{P}<0.05 ; \pm$ Standard Deviation 
Table.3 Variation in chlorophyll content induced by F stress in mung bean and spinach

\begin{tabular}{|l|c|c|c|c|c|c|}
\hline \multirow{2}{*}{ Treatment } & \multicolumn{3}{|c|}{ Mung bean } & \multicolumn{3}{c|}{ Spinach } \\
\cline { 2 - 7 } & Chl a & Chl b & Total Chl & Chl a & Chl b & Total Chl \\
\hline Control & $0.25^{\mathrm{a}}$ & $2.87^{\mathrm{a}}$ & $3.67^{\mathrm{a}}$ & $8.10^{\mathrm{a}}$ & $8.03^{\mathrm{a}}$ & $8.23^{\mathrm{a}}$ \\
\hline T1(0.01) & $0.06^{\mathrm{b}}$ & $2.33^{\mathrm{b}}$ & $3.57^{\mathrm{b}}$ & $2.33^{\mathrm{b}}$ & $3.20^{\mathrm{b}}$ & $4.49^{\mathrm{b}}$ \\
\hline T2(0.05) & $0.04^{\mathrm{b}}$ & $2.33^{\mathrm{b}}$ & $2.45^{\mathrm{a}}$ & $2.33^{\mathrm{b}}$ & $1.40^{\mathrm{c}}$ & $4.31^{\mathrm{b}}$ \\
\hline T3(1.00) & $0.03^{\mathrm{b}}$ & $0.30^{\mathrm{c}}$ & $2.29^{\mathrm{ab}}$ & $2.33^{\mathrm{b}}$ & $1.77^{\mathrm{c}}$ & $2.71^{\mathrm{c}}$ \\
\hline T4(1.15) & $0.01^{\mathrm{b}}$ & $0.30^{\mathrm{c}}$ & $2.00^{\mathrm{b}}$ & $1.06^{\mathrm{b}}$ & $1.37^{\mathrm{c}}$ & $2.39^{\mathrm{c}}$ \\
\hline
\end{tabular}

Where, Chl means chlorophyll $(\mathrm{mg} / \mathrm{l})$. Values with the same lower case letters in a column denote no significant difference at $\mathrm{P}<0.05 ; \pm$ Standard Deviation

Table.4 Correlation matrix among different growth physiological parameters of mung bean and spinach

\begin{tabular}{|l|c|c|c|c|c|c|}
\hline \multicolumn{1}{|c|}{ Parameters } & $\begin{array}{c}\text { Shoot length } \\
(\mathrm{cm})\end{array}$ & $\begin{array}{c}\text { Root length } \\
(\mathrm{cm})\end{array}$ & $\begin{array}{c}\text { Total Chl. } \\
(\mathrm{mg} / \mathrm{g})\end{array}$ & $\begin{array}{c}\text { Shoot wt. } \\
(\mathrm{g})\end{array}$ & $\begin{array}{c}\text { Root wt. } \\
(\mathrm{g})\end{array}$ & R:S ratio \\
\hline $\begin{array}{l}\text { Shoot length } \\
(\mathrm{cm})\end{array}$ & 1 & & & & & \\
\hline Root length $(\mathrm{cm})$ & 0.155 & 1 & & & & \\
\hline Total Chl. $(\mathrm{mg} / \mathrm{g})$ & -0.196 & $0.651^{* *}$ & 1 & & & \\
\hline Shoot wt. $(\mathrm{g})$ & $-0.378^{*}$ & $0.684^{* *}$ & $0.715^{* *}$ & 1 & & \\
\hline Soot wt. $(\mathrm{g})$ & $-0.452^{*}$ & $0.580^{* *}$ & $0.722^{* *}$ & $0.924^{* *}$ & 1 & \\
\hline R:S ratio & $-0.476^{* *}$ & $0.410^{*}$ & $0.549^{* *}$ & $0.755^{* *}$ & $0.936^{* *}$ & 1 \\
\hline Vigour index & $0.965^{* *}$ & 0.291 & -0.003 & -0.242 & -0.315 & $-0.376^{*}$ \\
\hline
\end{tabular}

Whereas, ${ }^{* *}$ Correlation is significant at the 0.01 level; ${ }^{*}$ Correlation is significant at the 0.05 level

Figure.1 Regression analysis between total chlorophyll and F concentration

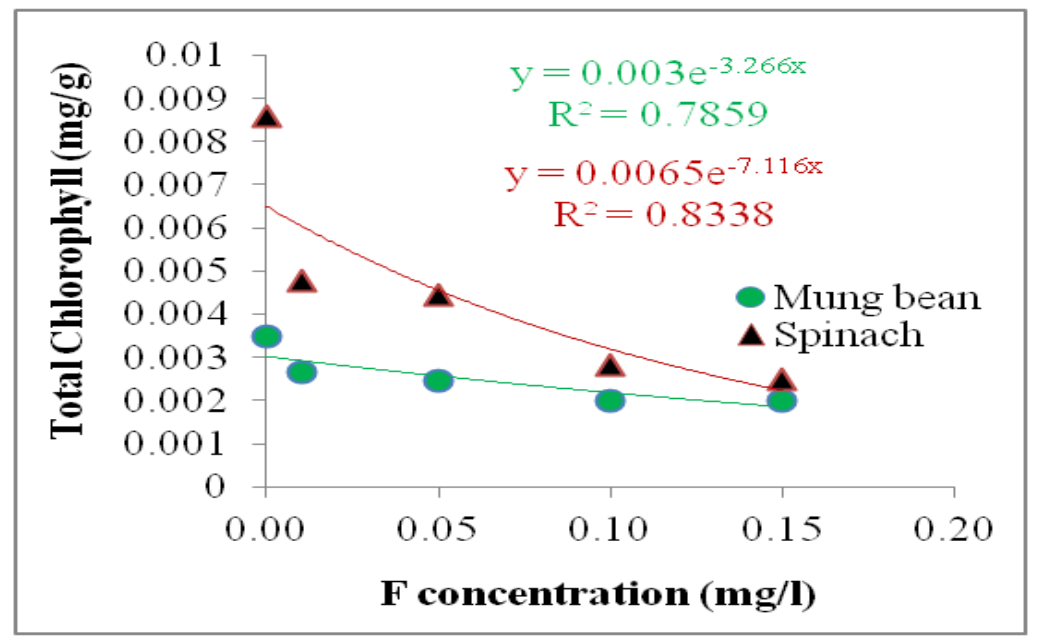




\section{Vigour index}

Seed vigour comprises those seed properties which determine the potential for rapid, uniform emergence. Vigor index showed a decreasing trend with increasing $\mathrm{F}$ concentration. Treatment with highest $F$ concentration $(0.15 \mathrm{mg} / \mathrm{l})$, showed decreased vigour index $88 \%$ in spinach followed by mung bean (Table 1). Such findings were also in confirmation with Tang et al., (1999) and Bhargava and Bhardwaj (2010) for Cicer arietinum and Triticum aestivum, respectively. Rapid embryo growth in control may be plausible having higher vigour index of the seeds. Shoot length was positively correlated with vigour index $\left(\mathrm{r}=0.965^{* *}\right)$, however root shoot ratio was negatively correlated (Table 3).

\section{Dry weight of mung bean and spinach}

Dry wt. of shoot and root as well as root: shoot ratio is a function of plant physiology and serves as an indicator for stress induced by different environmental pollutants. Shoot and root dry wt. of mung bean and spinach decreased monotonically with increased $\mathrm{F}$ concentration; this may be due to reduction of metabolic activity in presence of $\mathrm{F}$, which acts as a metabolic inhibitor (Sabal et al., 2006 and Gupta et al., 2009). Shoot dry wt. of mung bean and spinach reduced by $26.6 \%$ and $33 \%$, respectively compared to control (Table 2). Similar findings were also reported by Jha et al., (2009). However, the reduction in root dry wt. was statistically at par in mung bean and robust in spinach, this signifies the sensitive nature of spinach root to higher $\mathrm{F}$ concentration.

Shoot dry wt. was positively correlated $(\mathrm{p}<0.05)$ with root length, chl a, b and total chl., root dry wt. and root shoot ratio (Table $3)$. However, shoot dry wt. was negatively correlated with shoot length, seed germination and vigour index. This may be due to changes in biochemical parameters which in consequence retard the growth and biomass of plants (Mishra et al., 2014).

\section{Chlorophyll content}

The mechanism by which $F$ affects photosynthesis is mainly by reducing the synthesis of chlorophyll, degradation of chloroplasts, and inhibition of Hills reaction (Yamauchi et al., 1983). At highest $\mathrm{NaF}$ concentration $(0.15 \mathrm{mg} / \mathrm{l})$, total chlorophyll content in mung bean was reduced by $3 \%$ as compared to control. Whereas $25 \%$ reduction in total chlorophyll content was recorded in spinach compared to control (Figure 1). Such reduction in total chlorophyll content may be due to breakdown of chlorophyll during stress or inhibition of chlorophyll biosynthesis which is the primary symptom of $F$ induced chlorosis (Sreedevi and Damodharam, 2013).

In addition, this reduction may also be attributed to inhibitory action of $F$ with $\gamma$ amino levulinic acid into chlorophyll synthetic pathway (Wallis et al., 1974). Our results of regression analysis presented in figure 1, showed inverse relationship between total chlorophyll content and $\mathrm{F}$ concentration $\left(\mathrm{R}^{2}=0.786\right.$ and 0.834 corresponding to mung bean and spinach, respectively) was in confirmation with Baskaran et al., (2009) and Bhargava and Bhardwaj, (2010). Baskaran et al., (2009), observed reduction in chlorophyll content and justified by explaining the formation of enzymes chlorophyllase, which is responsible for chlorophyll degradation. Our results are in agreement with Baskaran et al., (2009) for mung bean and Bose et al., (1995) for spinach. Correlation matrixes of chlorophyll with other growth physiological parameters are presented in table 4 .

This study concludes that growth physiology of mung bean and spinach were negatively affected by the $F$ contamination of soil, however spinach is more sensitive than mung 
bean towards $\mathrm{F}$ contamination of the soil. Highest $\mathrm{F}$ concentration $(0.15 \mathrm{mg} / \mathrm{l})$, showed 88 and $47 \%$ decrease in vigour index of spinach and mung bean, respectively. However, total chlorophyll content was reduced by 3 and $25 \%$ of mung bean and spinach as compared to control. Shoot dry wt. and root dry weight was also observed to be more affected in spinach as compared to mung bean. This may have occurred because $\mathrm{F}$ is present in non-ionic form, hence, more readily taken up by cell membranes of plants.

\section{Acknowledgement}

The corresponding author acknowledge Institute of Environmental Studies, Kurukshetra University, Kurukshetra, Haryana for laboratory facilities and technical support during this study.

\section{References}

Amini, M., Mueller, K., Abbaspour, K.C., Rosenberg, T., Afyuni, M., Møller, K.N., Sarr, M., Johnson, C.A. 2008. Statistical modeling of global geogenic fluoride contamination in ground waters. Environ. Sci. Technol., 42: 3662-3668.

Anderson, Jo, A.S., Abdul-Baki. 1973. Vigor determination in soyabean seeds by multiple criteria. Crop Sci., 3: 630-633.

Arnon, D.I. 1949. Copper enzymes in isolated chloroplasts. Polyphenol oxidase in Beta vulgaris. Plant Physiol., 24: 115.

Bhargava, D., Bhardwaj, N. 2010. Effect of sodium fluoride on seed germination and Seedling growth of Triticum aestivum var. Raj. 4083. J. Phytol., 2(4): 41-43.

Baskaran, L., Sundaramoorthy, P., Chidambaram, A.L.A., and Ganesh, S.K. 2009. Growth and Physiological Activity of Greengram (Vigna radiata
L.) Under Effluent Stress. Bot. Res. Int., 2(2): 107-114.

Chakrabart, S., Patra, K.P. 2013. Effect of Sodium Fluoride on Seed Germination, Seedling Growth and Biochemistry of Paddy. Asian J. Experimental Biol. Sci., 4(4): 540-544.

Chang, C.W. 1966. Study of phytase and fluoride effects in germinating corn seeds. Air Poll. Res. Center, 44: 129142.

Gadi, B.R., Verma, P., Amra, R. 2012. Influence of $\mathrm{NaF}$ on seed germination, membrane stability and some biochemical content in Vigna seedlings. J. Chem. Biol. Physical Sci., 2(3): 13718.

Gupta, S., Banerjee, S., and Mondal, S. 2009. Phytotoxicity of fluoride in the germination of paddy (Oryza sativa) and its effects on the physiology and biochemistry of germinating seedlings. Fluoride, 42:142-146.

Jha, S.K., Nayek, A.K., and Sharma, Y.K. 2009. Fluoride toxicity effects in onion (Alium cepa L.) grown in contaminated soils. Chemosphere, 76: 353-356.

Mishra, P.C., Sahu, S.K., Bhoi, A.K., and Mohapatra, S.C. 2014. Fluoride Uptake and Net Primary Productivity of Selected Crops. Open J. Soil Sci., 4: 388-398.

Ramesh, M., Aruna, R.M., Malathi, N., Krishnan, R. 2014. A Review of fluoride and its diverse effects. SRM J. Res. Dent. Sci., 5: 42-5.

Pant, S.P., Pant, P.V., and Bhiravamurthy. 2008. Effects of fluoride on early root and shoot growth of typical crop plants of India. Fluoride, 41(1): 57-60.

Sabal, D., Khan, T.I. 2006. Effect of sodium fluoride on cluster bean (Cyamopsis tetragonoloba) seed germination and seedling growth. Fluoride, 39: 228-230.

Sreedevi, R., Damodharam, T. 2013. Exterminate consequence of $\mathrm{NaF}$ on 
seed germination and some morphological changes of major pulse crop Cicer aritinum L. Cv. Anuradha (Bengal gram). Asian J. Plant Sci. Res., 3(2): 38-41.

Tang, S., Tekrony, D.M., Egli, D.B., Cornelius, P.L., and Rucker, M. 1999. Survival Characteristics of Corn Seed during Storage: I. Normal Distribution of Seed Survival. Crop Sci., 39(5): 3941400.

Wallis, W.J., Miller, G.W., Psenak, M., and Shieh, J. 1974. Fluoride effects on chlorophyll biosynthesis. Fluoride, 7:
69-77.

Yamauchi, M., Choi, W.K., and Yamada, Y. 1983. Fluoride inhibition of photosynthesis in certain crop plants. Soil Sci. Plant Nutri., 29(4): 549-53.

$\mathrm{Yu}$, M.H. 1996. Effects of fluoride on growth and soluble sugars in germinating mung bean. Res. Report, 29(1): 3-6.

Zhang, J., Bei, Z., Zhang, Y., and C. 2014. Growth Characteristics, Water and Nitrogen Use Efficiencies of Spinach in Different Water and Nitrogen Levels. Sains Malaysiana, 43(11): 1665-1671.

\section{How to cite this article:}

Rakhi Tyagi, Jyoti Luhach, A.K. Mishra and Smita Chaudhry. 2017. Morphological and Biochemical Changes in Vigna radiata and Spinacia oleracea Induced by Fluoride Contamination in Soils. Int.J.Curr.Microbiol.App.Sci. 6(5): 395-402. doi: http://dx.doi.org/10.20546/ijcmas.2017.605.045 